Ambiente \& Água - An Interdisciplinary Journal of Applied Science
ISSN 1980-993X - doi:10.4136/1980-993X
www.ambi-agua.net
E-mail: ambi.agua@gmail.com

\title{
Environmental performance of a full-scale wastewater treatment plant applying Life Cycle Assessment
}

\author{
ARTICLES doi:10.4136/ambi-agua.2216
}

Received: 24 Nov. 2016; Accepted: 11 Jun. 2018

\author{
Thaís Andrade de Sampaio Lopes*; Luciano Matos Queiroz; \\ Asher Kiperstok \\ Universidade Federal da Bahia (UFBA), Salvador, BA, Brasil \\ Departamento de Engenharia Ambiental (DEA). E-mail: thaislopes84@yahoo.com.br, \\ lmqueiroz@ufba.br, asher@ufba.br \\ ${ }^{*}$ Corresponding author
}

\begin{abstract}
Life Cycle Assessment (LCA) was applied to estimate and analyze the environmental impacts from the construction and operation phases of a full-scale wastewater treatment plant (WWTP) located in the municipality of Lauro de Freitas, Bahia, Brazil. The WWTP process consists of the association of an Upflow Anaerobic Sludge Blanket (UASB) reactor followed by four constructed wetlands (CWL) and a disinfection step. The functional unit was defined as one cubic meter of treated effluent during the useful life of this WWTP (20 years). The LCA was carried out using SimaPro ${ }^{\circledR}$ software and the Centre of Environmental Science (CML) assessment method. The environmental impacts during construction phase were mainly from the wooden forms for concrete and the use of reinforcing steel. During the operation phase, the chlorine used as effluent disinfectant caused the greatest impacts in the abiotic depletion and acidification categories. Macronutrient concentrations present in the treated effluent and the methane generated also caused significant environmental impacts during the WWTP's useful life. The results obtained highlight the importance of the application of a methodology like LCA to assist in decision-making with regard to the implementation, construction and operation of a WWTP.
\end{abstract}

Keywords: life cycle assessment, UASB reactor, wastewater treatment.

\section{Desempenho ambiental de uma estação de tratamento de esgoto em escala real aplicando a Avaliação de Ciclo de Vida}

\section{RESUMO}

A Avaliação de Ciclo de Vida (ACV) foi aplicada para quantificar e analisar os impactos ambientais oriundos da construção e operação de uma estação de tratamento de esgotos (ETE) localizada no município de Lauro de Freitas, Bahia, Brasil. O processo de tratamento consiste de um reator UASB seguido de quatro wetlands construídos e uma etapa final de desinfecção. A unidade funcional foi definida como um mero cúbico de esgoto tratado durante a vida útil da ETE (20 anos). A ACV foi realizada por meio da utilização do software SimaPro ${ }^{\circledR}$ e o método de avaliação de impactos escolhido foi o CML. As fôrmas confeccionadas com madeira tratada e o aço CA 50 apresentaram maior potencial de geração de impactos ambientais para a fase de 
construção. Já na fase de operação, o uso do cloro como desinfetante resultou em maiores impactos nas categorias de depleção abiótica e acidificação. A presença de macronutrientes e a geração do gás metano, também, foram responsáveis por significativos impactos ambientais durante a vida útil da ETE. Os resultados demonstram a importância da aplicação de metodologia de avaliação de impactos ambientais como a ACV de modo a auxiliar na tomada de decisão para as fases de implantação, construção e operação dessas ETE.

Palavras-chave: avaliação de ciclo de vida, tratamento de esgotos, reator UASB.

\section{INTRODUCTION}

Wastewater treatment plants (WWTP) are designed to protect public health and minimize the environmental impacts of discharging untreated wastewater into natural aquatic systems. However, different WWTP have distinct performances and generate direct environmental impacts like any process that uses natural resources. Some WWTPs consume high amounts of energy, use chemicals and materials which have a high embodied energy (e.g. plastics), occupy large land areas, produce and release greenhouse gases and generate significant amounts of biological or chemical sludge (Corominas et al., 2013).

Therefore, the goals set for a specific WWTP need to move beyond the protection of human health and surface waters to include minimizing the loss of scarce resources, reducing the energy, water use and waste generation, besides enabling the recycling of water and macronutrients.

Life Cycle Assessment (LCA) has already been proven as a valid methodology to assess the environmental performance of WWTPs worldwide. Using a whole-process approach and addressing all relevant environmental impacts over the WWTP's useful life, the LCA allows an assessment that goes beyond the usual trade-off between treatment efficiency and effluent quality standards (Corominas et al., 2013; Risch et al., 2014; Zang et al., 2015).

The LCA methodology is able to measure and correlate the raw materials used, chemicals consumed, the quality of treated effluent, the biological or chemical sludge generated, gaseous and particulate matter emissions to one or more indicators characteristic of specific environmental impacts such as abiotic depletion or acidification of aquatic environments. These categories of environmental impacts are selected by the researcher to answer the objectives of their studies. Corominas et al. (2013) published a critical review of the literature about the application of the LCA methodology to evaluate the environmental impacts of wastewater treatment worldwide. The authors reviewed papers published between 1996 and 2012 and did not mention any Brazilian reference. Therefore, we can conclude that LCA studies in WWTPs are very incipient and scarce in Brazil.

One of the most critical points in an LCA study is finding reliable and specific data. The lack of reliable data on the input and output flows of the processes may lead to restrictions and cause uncertainties in the result and consequently an underestimation of environmental impacts (Opher and Friedler, 2016).

The aim of this paper was to evaluate the environmental performance of a full-scale WWTP located in Bahia state, Brazil, applying LCA methodology for the construction and operation phases. We also present a detailed Life Cycle Inventory (LCI) and the Life Cycle Impact Assessment for this specific WWTP.

\section{MATERIAL AND METHODS}

The object of this study was a full-scale WWTP designed for approximately 1,000 people, located in Lauro de Freitas city, Bahia state, Brazil. It has been operating since 2008 and 
consists of an Upflow Anaerobic Sludge Blanket (UASB) reactor followed by four constructed wetlands (CWL) and a disinfection step with the application of sodium hypochlorite solution $(\mathrm{NaOCl})$ in a contact basin.

The UASB reactor $(3.8 \times 3.8 \mathrm{~m} \times 5.1 \mathrm{~m})$, which corresponds to a cross-section of $14.4 \mathrm{~m}^{2}$, has an effective volume of $73.6 \mathrm{~m}^{3}$ and hydraulic retention time of 8.5 hours. The CWL consists of four parallel gravel-based cells, each $7.0 \mathrm{~m} \times 18 \mathrm{~m}$, with horizontal subsurface flow through a depth of $0.8 \mathrm{~m}$. Two cells were planted with Typha sp. and the other two were planted with Cyperus alternifolius sp. The design flow rate is equal to $96 \mathrm{~m}^{3}$ per day. A low-power electrical pump adds the sodium hypochlorite solution for disinfection.

In our work, the LCA was carried out using SimaPro ${ }^{\circledR}$ 8.0.1 PhD version. Data were collected from previous research, the construction project, operation reports of the WWTP and laboratory analyses. Pump specifications and properties of the construction materials were obtained from the websites of manufacturers and building materials suppliers. Inventory data were connected with processes of Ecoinvent ${ }^{\circledR}$ databases.

This study uses the CML 2 baseline 2000 Life Cycle Impact Assessment method that has been frequently used. Four impact categories have been chosen: abiotic depletion, global warming, acidification and eutrophication. The choice of impact categories was based on data availability and significance, i.e., these impact categories are related to the performance of the WWTP and are also those most frequently analyzed in similar studies.

The system boundary is limited to influent wastewater to the treatment plant until effluent is discharged into water bodies. The LCA focused on the construction and operation phases. Dismantling has been excluded, because the impact would be tiny compared to the construction and operation phases and this has been omitted in several LCA studies of wastewater treatment plants (Foley et al., 2010; Fuchs et al., 2011; Lopsik, 2013; Larrey-Lassale et al. 2017; Larsen, 2018).

Two system boundaries were defined. The first plan included a quantitative inventory of the WWTP (e.g. direct atmospheric emissions, effluent discharges). The second plan boundary was based on data from the Ecoinvent ${ }^{\circledR}$ database (e.g. construction materials production, chemical manufacture and electricity generation) available in SimaPro ${ }^{\circledR}$ (Figure 1), for the construction and operation phases.

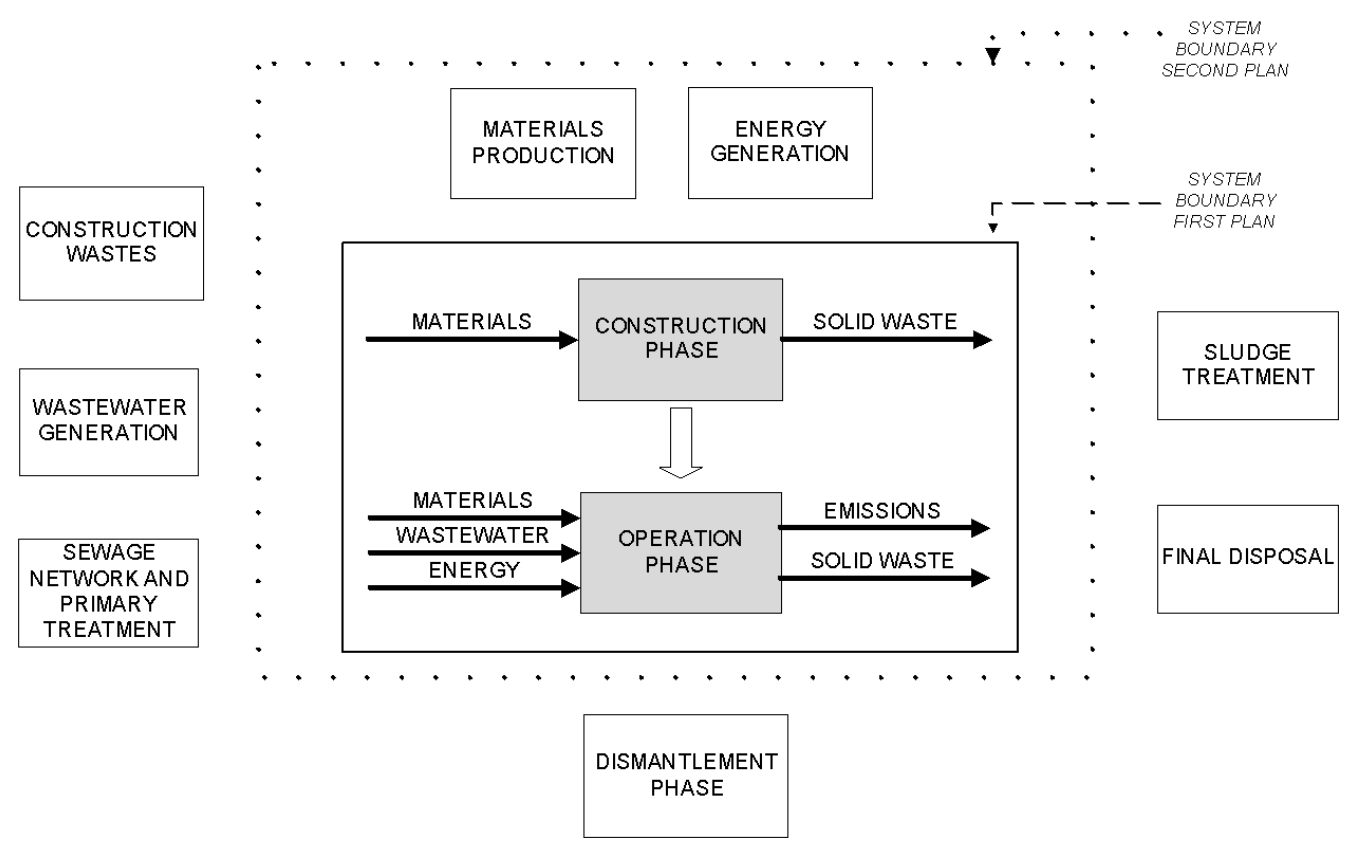

Figure 1. System boundaries of WWTP. 
It is important to highlight that the process of materials production available in the Ecoinvent ${ }^{\circledR}$ database does not refer to the Brazilian reality. However, Eicker et al. (2010) evaluated the difference between the inventory of the Brazilian reality and the Ecoinvent ${ }^{\circledR}$ database, showing that it can be applied to the characterization of Brazilian processes without loss of quality of information.

The study has been carried out by including the following aspects: construction materials, energy use, chemical consumption, treated effluent discharge, gaseous emissions and the expected useful life of the WWTP equal to 20 years. The operational report of this WWTP informs that it is necessary to replace the support material (gravel) of each CWL unit every five years due to clogging. Therefore, three substitutions were considered during the life cycle of the WWTP and have been taken into account in the LCI of the operation phase. The LCA did not include the wastewater collection and transport system, land use, pre-treatment (e.g. pump station, grease and sand traps), sludge treatment and demolition or construction waste because of the lack of data.

The following aspects and criteria were considered to elaborate the LCA of the operation phase: the flow rate, the microbiological and physicochemical characteristics of the influent and effluent, the electricity and chemical consumption, atmospheric emission, equipment and process specifications. The characteristics of the influent and effluent were obtained by collecting samples and conducting laboratory analyses over a period of eight months (data not shown). The following parameters were used to characterize the wastewater: chemical oxygen demand (COD), total and volatile suspended solids (TSS and VSS), ammonia, total Kjeldahl nitrogen (TKN), nitrate, total phosphorus and residual chlorine.

The analysis of wastewater treatment goals suggests as a functional unit one cubic meter of treated wastewater. Foley et al. (2010) and Larsen (2018) agree that this is a good choice because it comes from real data. Considering the design flow rate (four cubic meter per hour) and the 20-year useful life of the WWTP, the total volume of wastewater treated in the WWTP was $700800 \mathrm{~m}^{3}$.

The data quality depends on the availability, source and accuracy, which should be reported to estimate the degree of the LCA uncertainty. Faced with the availability or lack of data and the study assumptions, it is important to continuously improve the information in order to ensure data quality. The inventory data (Table 1) of the construction phase were collected and calculated from the construction project and data obtained from websites of manufacturers and construction materials suppliers.

The input data for the operation phase were: loads of pollutants present in the domestic wastewater, $\mathrm{NaOCl}$ solution applied during the disinfection step, electricity used by the sodium hypochlorite solution pump and the gravel changed each 5 years of the CWL operation. The output data were: loads of pollutants present in the treated effluent, gaseous emissions $\left(\mathrm{CH}_{4}\right.$ from anaerobic digestion), biological sludge and the contaminated gravel that is removed from the CWL beds each five years. The quantity of the replaced gravel was calculated based on the WWTP operational reports and the operation technicians informed that there is no reuse of the contaminated gravel.

The air emissions and sludge from the UASB reactor were based on the mass balance of the fractions of COD proposed by Souza et al. (2012). Air emissions $\left(\mathrm{CH}_{4}\right.$ and $\left.\mathrm{N}_{2} \mathrm{O}\right)$ from the CWL were obtained by equations reported by the Intergovernmental Panel on Climate Change (IPCC, 2013). 
Table 1. Life Cycle Inventory of construction and operation phase.

\begin{tabular}{|c|c|c|c|c|}
\hline Inputs (materials) & \multicolumn{2}{|c|}{ Quantity at the end of 20 years } & \multicolumn{2}{|c|}{ Correlated to functional unit } \\
\hline Reinfor Reinforcing steel & 38573.5 & $\mathrm{~kg}$ & 0.055 & $\mathrm{~kg} \mathrm{~m}^{-3}$ \\
\hline Portland cement & 54462.7 & $\mathrm{~kg}$ & 0.078 & $\mathrm{~kg} \mathrm{~m}^{-3}$ \\
\hline Sand & 174143.2 & $\mathrm{~kg}$ & 0.248 & $\mathrm{~kg} \mathrm{~m}^{-3}$ \\
\hline Gravel, round gravel & 1036444.8 & $\mathrm{~kg}$ & 1.479 & $\mathrm{~kg} \mathrm{~m}^{-3}$ \\
\hline Tap water & 37139.5 & $\mathrm{~kg}$ & 0.053 & $\mathrm{~kg} \mathrm{~m}^{-3}$ \\
\hline Pipes (PVC) & 1125.0 & $\mathrm{~kg}$ & 0.002 & $\mathrm{~kg} \mathrm{~m}^{-3}$ \\
\hline Sawnwood, Parana pine (BR) & 17.70 & $\mathrm{~m}^{3}$ & 0.001 & $\mathrm{~m}^{3} \mathrm{~m}^{-3}$ \\
\hline Brick & 1813.8 & $\mathrm{~kg}$ & 0.003 & $\mathrm{~kg} \mathrm{~m}^{-3}$ \\
\hline Glass fibre & 912.9 & $\mathrm{~kg}$ & 0.001 & $\mathrm{~kg} \mathrm{~m}^{-3}$ \\
\hline Inputs (Pollutants in Domestic wastewater) & \multicolumn{2}{|c|}{ Quantity at the end of 20 years } & \multicolumn{2}{|c|}{ Correlated to functional unit } \\
\hline Chemical oxygen demand (COD) & 538102.3 & $\mathrm{~kg}$ & 0.768 & $\mathrm{~kg} \mathrm{~m}^{-3}$ \\
\hline Suspended solids & 194843.4 & $\mathrm{~kg}$ & 0.278 & $\mathrm{~kg} \mathrm{~m}^{-3}$ \\
\hline Unionized ammonia $\left(\mathrm{NH}_{3}\right)$ & 26665.4 & $\mathrm{~kg}$ & 0.038 & $\mathrm{~kg} \mathrm{~m}^{-3}$ \\
\hline Total Kjeldahl nitrogen & 32341.9 & $\mathrm{~kg}$ & 0.046 & $\mathrm{~kg} \mathrm{~m}^{-3}$ \\
\hline Total phosphorus & 5080.8 & $\mathrm{~kg}$ & 0.007 & $\mathrm{~kg} \mathrm{~m}^{-3}$ \\
\hline Inputs (materials) & \multicolumn{2}{|c|}{ Quantity at the end of 20 years } & \multicolumn{2}{|c|}{ Correlated to functional unit } \\
\hline Gravel, round gravel & 648042.8 & $\mathrm{~kg}$ & 0.925 & $\mathrm{~kg} \mathrm{~m}^{-3}$ \\
\hline Sodium hypochlorite solution & 586607.1 & $\mathrm{~kg}$ & 0.837 & $\mathrm{~kg} \mathrm{~m}^{-3}$ \\
\hline Input (electricity) & \multicolumn{2}{|c|}{ Quantity at the end of 20 years } & \multicolumn{2}{|c|}{ Correlated to functional unit } \\
\hline Electricity, low voltage (BR) & 126144.0 & $\mathrm{kw}$ & 0.180 & $\mathrm{kw} \mathrm{m} \mathrm{m}^{-3}$ \\
\hline Emissions to air & \multicolumn{2}{|c|}{ Quantity at the end of 20 years } & \multicolumn{2}{|c|}{ Correlated to functional unit } \\
\hline Methane $\left(\mathrm{CH}_{4}\right)$ & 137545.1 & $\mathrm{~kg}$ & 0.196 & $\mathrm{~kg} \mathrm{~m}^{-3}$ \\
\hline Dinitrogen monoxide $\left(\mathrm{N}_{2} \mathrm{O}\right)$ & 401.5 & $\mathrm{~kg}$ & 0.001 & $\mathrm{~kg} \mathrm{~m}^{-3}$ \\
\hline Emissions to water (final treated effluent) & \multicolumn{2}{|c|}{ Quantity at the end of 20 years } & \multicolumn{2}{|c|}{ Correlated to functional unit } \\
\hline Biological oxygen demand (BOD) & 14962.1 & $\mathrm{~kg}$ & 0.021 & $\mathrm{~kg} \mathrm{~m}^{-3}$ \\
\hline Chemical oxygen demand (COD) & 66947.4 & $\mathrm{~kg}$ & 0.096 & $\mathrm{~kg} \mathrm{~m}^{-3}$ \\
\hline Suspended solids, unspecified & 12614.4 & $\mathrm{~kg}$ & 0.018 & $\mathrm{~kg} \mathrm{~m}^{-3}$ \\
\hline Unionized ammonia, $\left(\mathrm{NH}_{3}\right)$ & 27664.1 & $\mathrm{~kg}$ & 0.039 & $\mathrm{~kg} \mathrm{~m}^{-3}$ \\
\hline Total Kjeldahl nitrogen & 32061.6 & $\mathrm{~kg}$ & 0.046 & $\mathrm{~kg} \mathrm{~m}^{-3}$ \\
\hline Nitrate $\left(\mathrm{NO}_{3}{ }^{-}\right)$ & 1226.4 & $\mathrm{~kg}$ & 0.002 & $\mathrm{~kg} \mathrm{~m}^{-3}$ \\
\hline Total phosphorus & 5536.3 & $\mathrm{~kg}$ & 0.008 & $\mathrm{~kg} \mathrm{~m}^{-3}$ \\
\hline Chlorine & 546.6 & $\mathrm{~kg}$ & 0.001 & $\mathrm{~kg} \mathrm{~m}^{-3}$ \\
\hline Solid waste & \multicolumn{2}{|c|}{ Quantity at the end of 20 years } & \multicolumn{2}{|c|}{ Correlated to functional unit } \\
\hline Gravel, contaminated & 648042.8 & $\mathrm{~kg}$ & 0.925 & $\mathrm{~kg} \mathrm{~m}^{-3}$ \\
\hline
\end{tabular}

\section{RESULTS AND DISCUSSION}

Analyzing the results of the Life Cycle Impact Assessment of the construction phase (Figure 2), it can be stated that the reinforcing steel and wood are the materials responsible for the most of environmental impacts in all categories chosen, followed by Portland cement and gravel. The potential impact of reinforcing steel is due to its production, mainly because of the addition of some metals like chromium, molybdenum and to a lesser extent, nickel.

Although the use of gravel had the highest correlation with the functional unit in the LCI of the construction phase, it did not show a significant environmental impact. On the other hand, the wood showed a low correlation with the functional unit, and the use of this material during construction of the WWTP results in significant environmental impacts. Therefore, these results indicate that there is no direct relation between the amount of material used and its environmental impacts. The stages of extraction or production of these materials will determine the intensity and relevance of the environmental impacts for each selected category. 


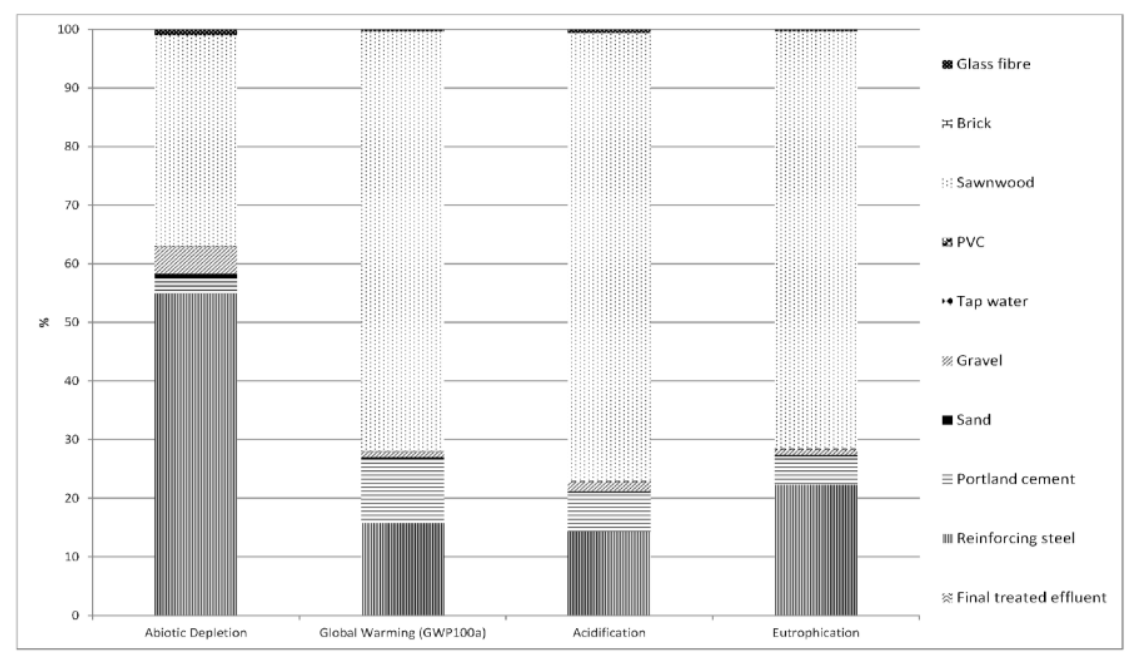

Figure 2. Assessment impact of the construction phase.

During the operation phase of the WWTP, the impacts were mainly caused by the use of the sodium hypochlorite solution in the disinfection step (Figure 3), considering the abiotic depletion and acidification categories. The methodology applied to construct the Ecoinvent ${ }^{\circledR}$ database accounts for high energy consumption in all steps of this chemical's production. Considering the global warming category, the greatest potential impact (80\%) was due to methane emissions resulting from the anaerobic digestion in the UASB reactor. However, the benefits of methane generation during anaerobic digestion could be achieved with the energy recovery from the combustion of this gas.

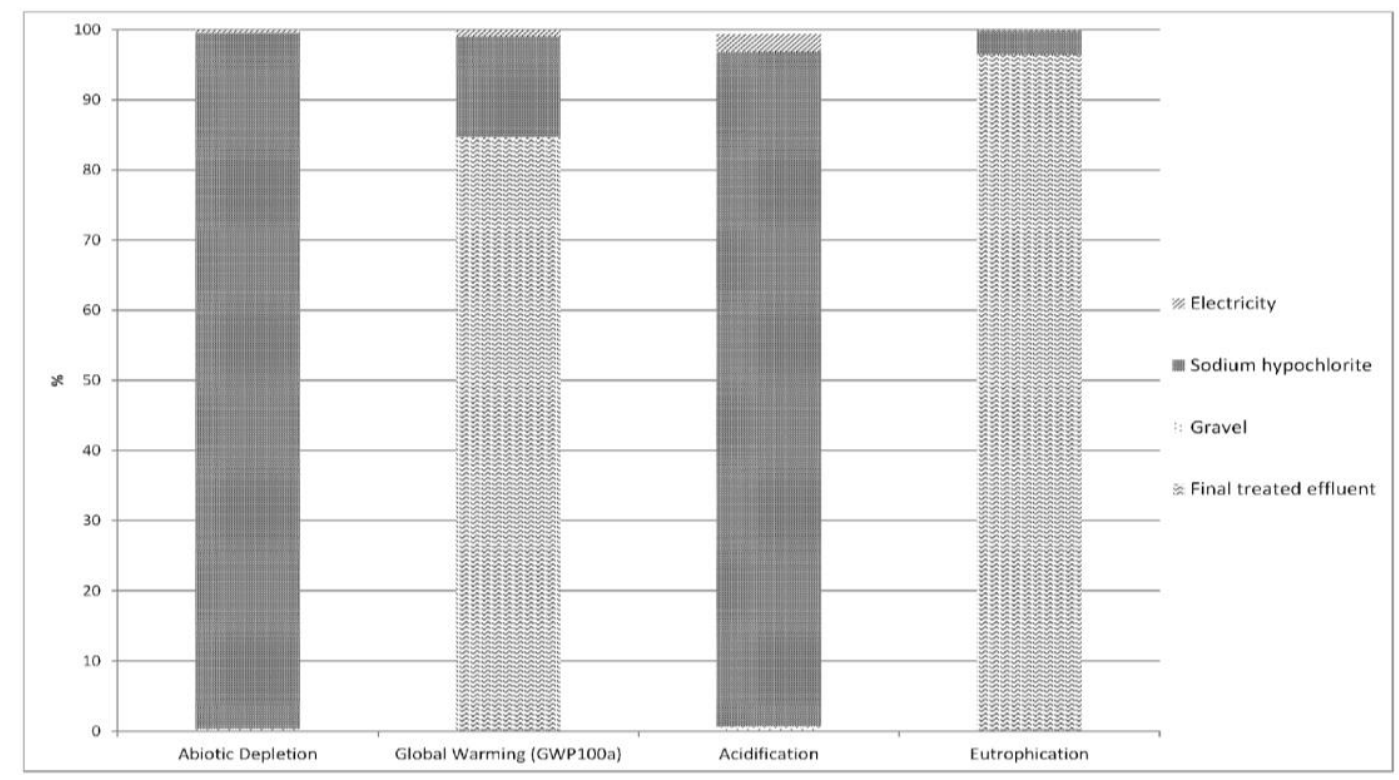

Figure 3. Assessment impact for operation phase.

Gaseous emissions (e.g. $\mathrm{CH}_{4}$ and $\mathrm{N}_{2} \mathrm{O}$ ) have a significant impact on the global warming category. According to the IPCC (2013), $\mathrm{CH}_{4}$ has a greenhouse effect 25 times greater than $\mathrm{CO}_{2}$ and $\mathrm{N}_{2} \mathrm{O}$ has 310 times more than $\mathrm{CO}_{2}$, indicating that scientists and engineers should pay more attention to the role of greenhouse gases in the assessment of the impacts from WWTPs, especially those that apply anaerobic digestion in some of their processes. The use of the thermal energy of this gas has proven to be an excellent alternative to mitigate the environmental impacts resulting from the use of UASB reactors (Bressani-Ribeiro et al., 2017). 
The wastewater treatment process was not effective in removing nitrogen and phosphorus and these pollutants present in treated effluent were responsible for the impacts (more than 90\%) in the eutrophication category. Eutrophication needs to be considered as a key category in LCA studies of WWTP because the results define the trade-off between operating costs and effluent quality. It is well established that phosphorus is the limiting nutrient for occurrence of eutrophication in aquatic environments. Saeed and Sun (2017) carried out a broad review of the literature on the nutrient removal in horizontal subsurface flow constructed wetlands. These authors concluded that the removal of phosphorus were only possible with the insertion of Padsorbing materials in the filter bed. The CWL filter beds are filled with gravel, which certainly does not allow high efficiencies of phosphorus removal during the treatment process.

The use of a sodium hypochlorite solution shows significant environmental impacts, mainly for abiotic depletion and acidification categories. Chemicals require a lot of resources and energy for their manufacture and our LCA study also considered the environmental impacts associated with the transportation logistics of these products to the WWTP site. We can conclude that the use of chemicals to remove microorganisms and improve the quality of treated effluent caused a decrease in the environmental performance of the WWTP. However, this final disinfection step is mandatory to meet the requirements of Brazilian environmental legislation, therefore, technicians and designers should investigate the effectiveness of environmentally less aggressive options for disinfection of treated effluent as sand filters or even membrane filtration, for example.

It was found from the analysis that the use of electricity for the operation phase has a lesser impact on the WWTP. These results are probably because the input data was based on the Brazilian energetic matrix, which is dominated by hydropower plants. Nevertheless, the electricity used to extract or produce construction materials such as gravel, sand and Portland cement and also sodium hypochlorite solution fabrication came from the Ecoinvent ${ }^{\circledR}$ database, which takes into account the European energy matrix based on fossil fuels. This is an important limitation of our study and should be taken into account by decision-makers. The reduction of the uncertainty of the results of the LCA study conducted in Brazil demands the construction of a Brazilian database. Although difficult and time-consuming, this task must be progressively accomplished.

Hence, a careful LCA study of the production of sodium hypochlorite solution with data obtained from Brazilian manufacturers is recommended. The production process reported in our study is more consistent with the European process, which may have overestimated the environmental impacts.

The comparative analysis between the two phases (Figure 4) confirms that the environmental impacts resulting from the WWTP operation are more significant than those of the construction for all the categories selected. Considering the acidification category, the construction phase has more than $40 \%$ of potential impact mainly because of the diesel fuel used in machines for the production of round wood according to the Ecoinvent ${ }^{\circledR}$ database.

Over the WWTP's life cycle the greatest environmental impacts contributing were as follows: the final effluent, operation and, to a lesser extent, the construction. The most relevant impact for the operation phase confirms those of other LCA studies on wastewater treatment (Lopsik, 2013; Paéz et al., 2017; Garfí et al., 2017; Sabeen et al., 2018). Some researchers have exempted the construction phase, arguing that this phase has little impact compared to the impact of the whole lifecycle WWTP (Hospido et al., 2007). The impact from the construction phase depends on the technology used in the wastewater treatment process (e.g. wetlands, UASB reactor and conventional activated sludge), so this is an assertion that needs to be assessed very carefully case by case.

Lopsik (2013) applied LCA in CWL showing that the greatest impact during the construction phase was due to the use of lightweight expanded clay aggregate as a support

\section{IPABH}

Rev. Ambient. Água vol. 13 n. 4, e2216 - Taubaté 2018 
material, indicating that the use of a new material can add a greater potential impact in an environmentally simple system. Studies analyzing activated sludge systems found a larger impact on the operation due to the high energy consumption (Gallego et al., 2008). Vlasopoulos et al. (2006) mentioned that the environmental impact of the construction phase may vary from 1 to $96 \%$ of the WWTP total impact. It will depend on the technology and the impact assessment method. The authors also emphasized that the comparison between different designs causes variations in the results for the categories of impact. In a general way, among a variety of technologies, anaerobic reactors and CWL have good environmental performance due to the low complexity and mechanization and low energy consumption (Sabeen et al., 2018).

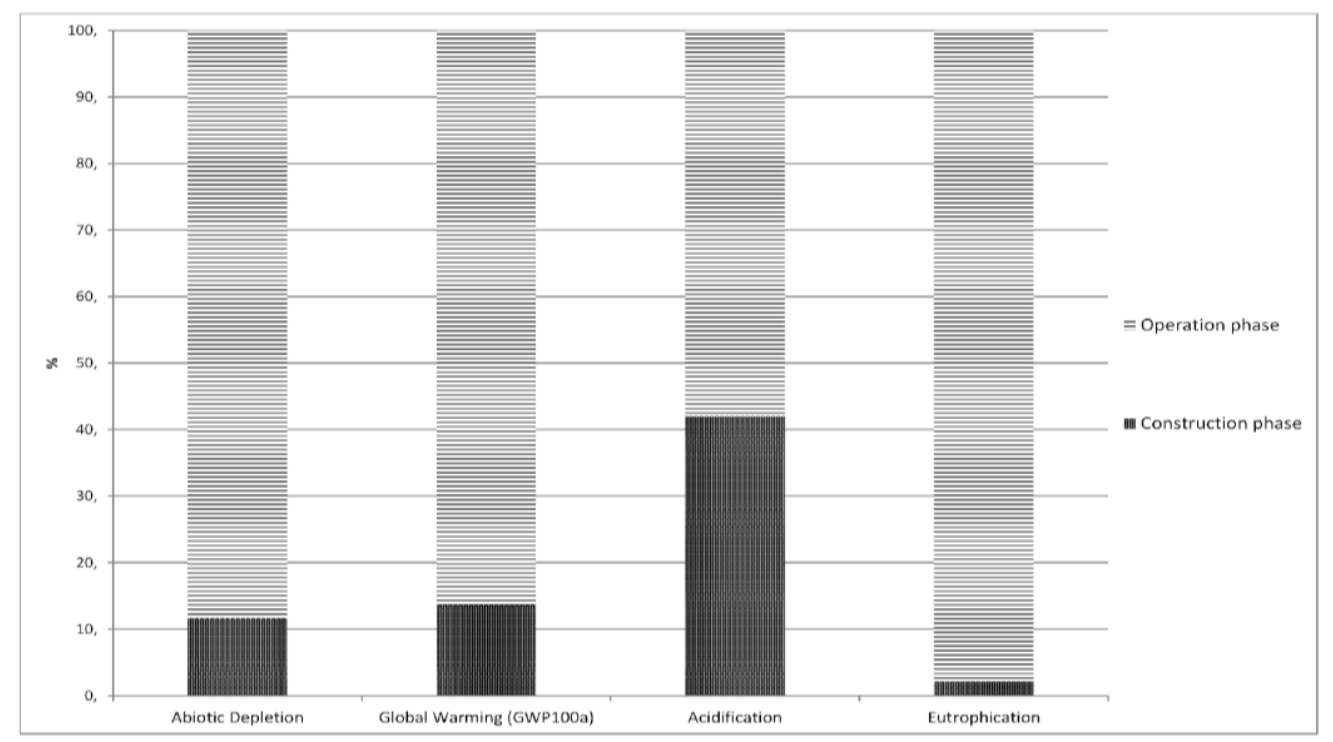

Figure 4. Construction versus operation phase.

Therefore, improving the quality of the final effluent results in a greater demand for natural resources, high energy consumption, chemical and operational complexity, in addition to the increased of the greenhouse gases emissions. It is very important to encourage rational use of water to reduce the generation of domestic wastewater, as well as to implement resourceoriented sanitation practices in order to minimize the environmental impacts of the WWTP.

\section{CONCLUSION}

LCA applied to a wastewater treatment plant (WWTP), a process comprised of anaerobic digestion in a UASB reactor followed by four constructed wetlands and a final effluent disinfection step, allowed concluding that:

- The use of reinforcing steel and wood during the construction of the WWTP was responsible for the most of environmental impacts in all LCA categories chosen. However, the results indicated that there is no direct relation between the amount of material used and its environmental impacts.

- Two aspects should be prioritized for the mitigation of environmental impacts during the operation of the WWTP: the reduction of methane gas emissions in the UASB reactor and the removal or recovery of the macronutrients present in the final effluent.

- The environmental impacts resulting from the WWTP operation are more significant than those of the construction for all the categories selected.

- The LCA proved to be a valid methodology for quantification of the environmental impacts associated with the domestic wastewater treatment in WWTPs. 


\section{ACKNOWLEDGEMENTS}

The authors would like to thank the Foundation for Research Support of the State of Bahia (Fapesb), the National Council for Scientific and Technological Development (CNPq) and the Brazilian Company of Innovation and Research (FINEP) for the provision of scholarships and financial support that made it possible to carry out this research.

\section{REFERENCES}

BRESSANI-RIBEIRO, T.; BRANDT, E. M. F.; GUTIERREZ, K. G.; DÍAZ, C. A.; GARCIA, G. B.; CHERNICHARO, C. A. L. Potential of resource recovery in UASB/trickling filter systems treating domestic sewage in developing countries. Water Science and Technology, v. 75, p. 1659-1666, 2017. http://dx.doi.org/10.2166/wst.2017.038

COROMINAS, L.; FOLEY, J.; GUEST, J. S.; HOSPIDO, A.; LARSEN, H. F.; MORERA, S. et al. Life cycle assessment applied to wastewater treatment: state of the art. Water Research, v. 47, p. 5480-5492, 2013. https://doi.org/10.1016/j.watres.2013.06.049

EICKER, M. O.; HISCHIER, R.; KULAY, L. A.; LEHMANN, M.; ZAH, R.; HURNI, H. The applicability of non-local LCI data for LCA. Environmental Impact Assessment Review, v. 30, p. 192-199, 2010. https://doi.org/10.1016/j.eiar.2009.08.007

FOLEY, J.; HAAS, D.; HARTLEY, K.; LANT, P. Comprehensive life cycle inventories of alternative wastewater treatment systems. Water Research, v. 44, p. 1654-1666, 2010. https://doi.org/10.1016/j.watres.2009.11.031

FUCHS, V. J.; MIHELCIC, J. R.; GIERKE, J. S. Life cycle assessment of vertical and horizontal flow constructed wetlands for wastewater treatment considering nitrogen and carbon greenhouse gas emissions. Water Research, v. 45, p. 2073-2081, 2011. https://doi.org/10.1016/j.watres.2010.12.021

GALLEGO, A.; HOSPIDO, I.; MOREIRA, M. T.; FEIJOO, G. Environmental performance of wastewater treatment plants for small populations. Resources, Conservation and Recycling, v. 52, p. 931-940, 2008. https://doi.org/10.1016/j.resconrec.2008.02.001

GARFÍ, M.; FLORES, L.; FERRER, I. Life Cycle Assessment of wastewater treatment systems for small communities: Activated sludge, constructed wetlands and high rate algal ponds. $\begin{array}{lllllll}\text { Journal of Cleaner Production, v. 161, p. 211-219, } 2017 . & \end{array}$ https://doi.org/10.1016/j.jclepro.2017.05.116

HOSPIDO, A.; MOREIRA, M. T.; FEIJOO, G. A comparison of municipal wastewater treatment plants for big centers of population in Galicia (Spain). International Journal of Life Cycle Assessment, v. 13, n. 1, p. 57-64, 2007. https://doi.org/10.1065/lca2007.03.314

INTERGOVERNMENTAL PANEL ON CLIMATE CHANGE. Adoption and acceptance of the "2013 supplement to the 2006 guidelines: wetlands". Georgia, 2013.

LARREY-LASSALLE, P.; CATEL, L.; ROUX, P.; ROSENBAUM, R. K.; LOPEZ-FERBER, M.; JUNQUA, G. et al. An innovative implementation of LCA within the EIA procedure: lessons learned from two wastewater treatment plant case studies. Environmental $\begin{array}{llllll}\text { Impact Assessment } & \text { Review, } & \text { v. 63, }\end{array}$ https://doi.org/10.1016/j.eiar.2016.12.004 
LARSEN, H. F. LCA of wastewater treatment. In: HAUSCHILD, M.; ROSENBAUM, R.; OLSEN, S. (Eds.). Life Cycle Assessment. New York: Springer, 2018. p. 861-886.

LOPSIK, K. Life cycle assessment of small-scale constructed wetland and extended aeration activated sludge wastewater treatment system. International Journal of Environmental Science Technology, v. 10, p. 1295-1308, 2013. https://doi.org/10.1007/s13762-012$0159-\mathrm{y}$

OPHER, T.; FRIEDLER, E. Reducing inventory data requirements for scenario representation in comparative life cycle assessment (LCA), demonstrated on the urban wastewater system. Urban Water Journal, v. 13, n. 7, p. 759-772, 2016. https://doi.org/10.1080/1573062X.2015.1036084

PAÉZ, J. I. P.; CARVALHO, A.; PRADO-RUBIO, O. A.; RÓMAN-MARTÍNEZ, A. Assessment of sustainable wastewater treatment networks design applying LCA. Computer Aided Chemical Engineering, v. 40, p. 2707-2712, 2017. https://doi.org/10.1016/B978-0-444-63965-3.50453-0

RISCH, E.; LOUBET, P.; NÚÑEZ, M.; ROUX, P. How environmentally significant is water consumption during wastewater treatment: application of recent developments in LCA to WWT technologies used at 3 contrasted geographical locations. Water Research, v. 57, p. 20-30, 2014. https://doi.org/10.1016/j.watres.2014.03.023

SABEEN, A. H.; NOOR, Z. Z.; NGADI, N.; ALMURAISY, S.; RAHEEM, A. B. Quantification of environmental impacts of domestic wastewater treatment using life cycle assessment: a review. Journal of Cleaner Production, v. 190, p. 221-223, 2018. https://doi.org/10.1016/j.jclepro.2018.04.053

SAEED, T.; SUN, G. A comprehensive review on nutrients and organics removal from different wastewaters employing subsurface flow constructed wetlands. Critical Reviews in Environmental Science and Technology, v. 47, p. 203-288, 2017. https://doi.org/10.1080/10643389.2017.1318615

SOUZA, C. L.; CHERNICHARO, C. A. L.; MELO, G. C. B. Methane and hydrogen sulfide emissions in UASB reactors treating domestic wastewater. Water Science and Technology, v. 65, p. 1229-1337, 2012. http://dx.doi.org/10.2166/wst.2012.854

VLASOPOULOS, N.; MEMON, F. A.; BUTLER, D.; MURPHY, R. Life Cycle Assessment of wastewater treatment technologies treating petroleum process waters. Science of the $\begin{array}{llllll}\text { Total Environment, } & \text { v. 367, } & \text { p. } & \text { 58-70, }\end{array}$ https://doi.org/10.1016/j.scitotenv.2006.03.007

ZANG, Y.; LI, Y.; WANG, C.; ZHANG, W.; XIONG, W. Towards more accurate Life Cycle Assessment of biological wastewater treatment plants: a review. Journal of Cleaner Production, v. 107, p. 676-692, 2015. https://doi.org/10.1016/j.jclepro.2015.05.060 